\title{
OBÓZ KONCENTRACYJNY JAKO NARZĘDZIE WŁADZY I TRANSFORMACJI SPOŁECZNEJ W XX WIEKU
}

Obozy koncentracyjne powstawały na długo przed drugą wojną światową. Pierwsze na Kubie - hiszpański generał Valeriano Weyler y Nicolau podczas walk z powstańcami skoncentrował w 1896 roku około 400 tys. starców, kobiet i dzieci, odcinając powstańców od zaplecza (Kamiński 1990, s. 33). Po wygranej w wojnie z Hiszpanią Stany Zjednoczone Ameryki, dławiąc opór powstańców, wprowadziły koncentrację ludności na Filipinach (Birtle 1997). Następnie Brytyjczycy założyli obozy dla Burów w czasie wojny imperialnej 1899-1902 (van Heyningen 2010). Cesarskie Niemcy w Afryce Południowo-Zachodniej zamykały członków ludów Herero i Nama w obozach, które zapowiadały już wiele okrucieństw drugiej wojny światowej (Olusoga, Erichsen 2012). Przykładów można podać znacznie więcej, także z okresu po ostatniej wojnie światowej - na przykład brytyjskie obozy koncentracyjne w Kenii (Elkins 2013) czy obozy w czasie wojny w Bośni i Hercegowinie (Walkiewicz 2000).

Kluczowe znaczenie w społecznej świadomości, ale również dla badaczy, ma jednak system obozów niemieckich z lat 1933-1945. Niemieckie obozy początkowo służyły nazistom do walki z przeciwnikami politycznymi. Pierwsze założył minister spraw wewnętrznych (i późniejszy premier Prus) Hermann Göring. Niemal równocześnie powstawały obozy „konkurencyjne" (w Szczecinie, Wrocławiu, w pobliżu Berlina), zwalczane przez 
Göringa. Kolejnym inicjatorem systemu obozowego stał się Heinrich Himmler, który w 1933 roku w pobliżu Dachau założył obóz pod komendą Theodora Eickego. Rywalizację w 1934 roku wygrał Himmler, uzyskując kontrolę nad wszystkimi obozami (Hilberg 2014, s. 1070-1071; por. Wachsmann 2016). Obozy koncentracyjne trzeba odróżniać od obozów zagłady — te drugie powstały dopiero wtedy, gdy zdecydowano, że „ostateczne rozwiązanie kwestii żydowskiej” dokona się na drodze eksterminacji.

Obozy koncentracyjne są dla socjologów szczególnym przedmiotem badawczym. W obozie możemy obserwować społeczność więźniów wyrwanych ze swego normalnego życia, odartych z symboli statusu w patologicznych warunkach stworzonych przez strażników. Jest to zatem rodzaj eksperymentu naturalnego pozwalającego dostrzec, które wartości, normy i zasady zostają zachowane w sytuacji powszechnego zagrożenia życia, głodu i epidemii (Abel 1951). Literatura na ten temat jest bogata, ale nie zawsze mamy do czynienia z systematycznym stawianiem socjologicznych pytań badawczych i wykorzystywaniem teorii i koncepcji nauk społecznych. Spośród prac socjologicznych należy wymienić ważną w Polsce książkę Anny Pawełczyńskiej Wartości a przemoc. Zarys socjologicznej problematyki Oświęcimia (1973). Autorka od maja 1943 roku do października 1944 była więziona w obozie w Birkenau, wykorzystała zatem swoje przeżycia (formalnie nie była to jednak obserwacja uczestnicząca). Badano różne wymiary życia obozowego. Krzysztof Konecki (1985) na przykład, sięgając do koncepcji interakcjonizmu symbolicznego i rozważań Ervinga Goffmana o instytucjach totalnych, opisał kształtowanie jaźni więźniów, w tym ich strategie obronne. Przedmiotem systematycznych analiz uczyniono także społeczne warunki udanych powstań więźniów, w tym w obozach zagłady (zob. Maher 2010), walkę o władzę nad obozem między różnymi aktorami nazistowskiego państwa (Goeschel 2010), socjalizację dzieci w obozie koncentracyjnym (Witek-Malicka 2013) czy gwarę obozową (Wesołowska 1996). A to tylko kilka przykładów z niezwykle bogatej i zróżnicowanej literatury przedmiotu.

Na podstawie porównania wybranych systemów obozów przedstawię tutaj rolę tych instytucji jako narzędzi władzy, służących zarówno utrzymaniu status quo, jak i transformacji społecznej. Opiszę zarówno cechy wspólne obozów koncentracyjnych, jak i te ograniczone do ich podtypów. Rozważania te mieszczą się $\mathrm{w}$ polu socjologii historycznej i genocide studies, czerpię bowiem $\mathrm{z}$ dorobku obu tych obszarów tematycznych. 


\section{CZYM JEST OBÓZ KONCENTRACYJNY?}

Wbrew pozorom bardzo trudno jest zdefiniować obóz koncentracyjny. Dostępne definicje słownikowe są niezadowalające, zwłaszcza gdy bierzemy pod uwagę zróżnicowane formy obozów w XX wieku. Bez wątpienia nazwa oddaje główną cechę - koncentrację ludności bez jej zgody w celu jej izolacji. Ale to łączy obóz koncentracyjny z takimi instytucjami, jak więzienia, szpitale psychiatryczne, getta, obozy pracy czy obozy jenieckie. Obóz koncentracyjny jest bowiem wiązką różnych funkcji, które mogą być wobec siebie konkurencyjne. Niemiecki system obozowy w czasie drugiej wojny światowej był bardzo rozbudowany i łączył obozy o różnych nazwach i funkcjach. Obozy koncentracyjne pełniły zaś jednocześnie takie funkcje, jak izolacja, kara, eksploatacja siły roboczej, wydobywanie zeznań, eksterminacja, przetrzymywanie zakładników czy nawet „wychowanie" (dzieci i małoletnich; zob. Grabowska 1977, s. 36). Niektóre z tych funkcji realizowały $\mathrm{w}$ tym samym czasie również inne nazistowskie instytucje. Różnice między nimi często były różnicą skali, a nie jakości. Na przykład do aresztów i więzień trafiały konkretne osoby, podejrzane o popełnienie przestępstw lub skazane wyrokami sądowymi, ale osadzano tam także tych, którzy na celowniku aparatu sprawiedliwości znaleźli się jako członkowie stygmatyzowanych kategorii społecznych (np. narodów okupowanych), a samo śledztwo było częścią rasistowskiej polityki okupacyjnej. Jednocześnie do obozów koncentracyjnych trafiały osoby, które traktowano jako członków wrogich kategorii społecznych (co uwidaczniał system obozowych „winkli”), ale zarazem zamykano w nich tych, którzy popełnili konkretne przestępstwa w świetle nazistowskiego prawa, na przykład homoseksualnych mężczyzn.

Pierwsze obozy koncentracyjne pełniły niewiele funkcji. Miały na celu izolowanie ludności cywilnej w czasie wojny partyzanckiej. Amerykanie i Anglicy zamykali Filipińczyków i Burów po to, aby odciąć partyzanckie oddziały od zaplecza. Masowa śmiertelność była w tych obozach przede wszystkim następstwem panujących tam warunków. Największe żniwo zbierały epidemie. Nie stosowano rozbudowanego systemu niewolniczej pracy czy tortur i kar. Podobne rozwiązania pojawiały się także później w czasie wojen partyzanckich, na przykład w Algierii, gdzie Francuzi prowadzili politykę „przegrupowywania” ludności wiejskiej, czyli przymusowego deportowania jej do strzeżonych obozów — bez opieki medycznej, pracy czy nauki. Do końca wojny znalazło się w nich około dwóch milionów Algierczyków, a więc co piąty mieszkaniec kraju (Modrzejewska-Leśniewska 2006, s. 376; szerzej: Sutton 1977, s. 286). 
Aby zatem zrozumieć rolę obozów, należy uwzględnić kontekst społeczny. Bez wątpienia wpływ na funkcjonowanie obozów ma występowanie lub nie wojny partyzanckiej, wojny międzypaństwowej, rewolucji lub buntu społecznego, ludobójstwa. Gdy radykałowie planują głęboką transformację społeczną, to obozy zyskują nowe funkcje. Jednak radykalna zmiana społeczna może również przebiegać bez tworzenia obozów koncentracyjnych. Niemcy i sojusznicy stworzyli zarówno system obozów koncentracyjnych, jak i obozów zagłady, które odgrywały kluczową rolę w ludobójstwie Żydów i Romów. Z kolei Hutu i Turcy dokonali totalnego ludobójstwa bez stworzenia systemu obozów (odpowiednio w Rwandzie w 1994 roku i w Imperium Osmańskim w latach 1915-1918), choć w tym drugim przypadku można mówić o docelowych miejscach koncentracji na pustyni (które jednak były „obozami zagłady”).

Doświadczenia drugiej wojny światowej nadały pojęciu obozu koncentracyjnego szczególnie negatywne konotacje. Dlatego dziś bardzo trudno używać go bez budzenia sporych emocji. Przykładem jest publiczna dyskusja o „polskich obozach koncentracyjnych” po drugiej wojnie światowej (zob. Łuszczyna 2017), choć powojenne obozy w Polsce często nie tylko korzystały $z$ infrastruktury obozów niemieckich, ale również pełniły niektóre funkcje nazistowskich obozów koncentracyjnych (Nowak 2002). W dyskusji tej rzadko wspomina się obóz w Berezie Kartuskiej z okresu międzywojennego, który jeszcze lepiej spełniał powszechne wyobrażenia obozu koncentracyjnego (Śleszyński 2003). Nie jest to tylko polska specyfika - w Stanach Zjednoczonych na przykład spore emocje od lat siedemdziesiątych XX wieku budziła debata na temat wojennych obozów internowania dla Japończyków jako obozów koncentracyjnych. Jednym z pierwszych naukowców, którzy nazwali je obozami koncentracyjnymi, jest Roger Daniels, który w 1971 roku opublikował książkę Concentration Camps USA: Japanese Americans and World War II (szerzej zob. Filinowicz 2013). Podobna sytuacja pojawia się, gdy badacze genocide studies rozstrzygają, czy w danym przypadku mieliśmy do czynienia z ludobójstwem. Odmowa takiej kwalifikacji jakiegoś przypadku prowadzi do oskarżeń o uprzedzenia, interesy polityczne lub brak uznania dla cierpienia ofiar. Jednak rezygnacja $z$ tych obciążonych terminów i zastąpienie ich technicznymi neologizmami nie wydają się ani płodne poznawczo, ani skuteczne w obiegu naukowym.

Niektórzy badacze stosują pojęcie obozu koncentracyjnego nie po to, aby włączać się w konflikty o interpretację przeszłości, ale by wzmocnić swój przekaz krytyczny. Przykładem może być Giorgio Agamben (2008b), który uznał obóz koncentracyjny za biopolityczny paradygmat nowoczesności. W tej perspektywie za nowoczesne obozy koncentracyjne można 
uznać nie tylko obozy dla uchodźców czy więzienie w Guantanamo, ale także państwowe domy starców. Mówi się także o obozach w sensie negatywnym (np. ośrodki zatrzymań) i pozytywnym (np. grodzone osiedla dla bogaczy). To dodatkowo rozmywa termin i czyni debatę naukową bardziej emocjonalną. Oczywiście, badacze tego nurtu wprowadzają ograniczenia: „W tym kontekście mówić można o fundamentalnej różnicy między obozami koncentracyjnymi i dzisiejszymi obozami: inaczej niż te pierwsze, drugie odwołują się do sytuacji wyboru" (Diken 2011, s. 134). Nie ma tu miejsca na rozwijanie tego tematu.

Myśląc dziś o obozach koncentracyjnych najczęściej przywołujemy obrazy Auschwitz-Birkenau, z ikonicznymi ogrodzeniami z drutu kolczastego, dymiącymi krematoriami i więźniami w pasiakach. Tymczasem w historii mieliśmy do czynienia z obozami, które były bardzo odległe od tego modelu. Najlepszym przykładem są komuny rolnicze w Kambodży rządzonej przez Czerwonych Khmerów, w których zmuszano do pracy, torturowano i zabijano wielu przesiedlonych mieszkańców kraju. Demokratyczna Kampucza, pełna „pól śmierci”, cała zamieniła się w wielki system obozów koncentracyjnych, choć bez drutów kolczastych pod napięciem i krematoriów (Jelonek 2008, s. 157). Naturalnie, istniały także ciężkie więzienia, jak niesławne więzienie założone w byłej szkole Tuol Sleng, nazwane S-21, w którym torturowano, jak się szacuje, 14-30 tys. ludzi. Jednocześnie niektóre obozy jenieckie doby drugiej wojny światowej były de facto obozami koncentracyjnymi, a nawet obozami śmierci dla niektórych kategorii społecznych - na przykład dla żołnierzy Armii Czerwonej w obozach niemieckich (Niemcy zabili około 3,1 mln sowieckich jeńców; umieralność w obozach jenieckich dla czerwonoarmistów wynosiła $57,5 \%$; Snyder 2011, s. 204, 207) czy Chińczyków w obozach japońskich (żołnierze chińscy często byli mordowani zaraz po wzięciu do niewoli; Margolin 2009, s. 289).

$\mathrm{Z}$ uwagi na te trudności nie podam tutaj definicji obozu koncentracyjnego. Zamiast tego przedstawię listę systemów obozów, które stały się przedmiotem moich porównań (tabela 1). Nie są to wszystkie systemy obozów. Nie wspominam, poza chorwackimi, o obozach prowadzonych przez sojuszników III Rzeszy. Pomijam także na przykład chińskie (komunistyczne), włoskie (faszystowskie) czy frankistowskie obozy koncentracyjne. O doborze przypadków zdecydowała ich reprezentatywność, umiejscowienie na linii czasu, dostępność literatury przedmiotu oraz moja znajomość poszczególnych systemów obozów. W przypadku japońskich obozów pomijam męczeństwo zachodnich jeńców wojennych (zob. Margolin 2009, s. 285-320; Yap 2012). 
Porównywane systemy obozów koncentracyjnych

\begin{tabular}{|c|c|c|c|c|}
\hline Państwo-organizator & Ofiary & $\begin{array}{l}\text { Okres } \\
\text { funkcjono- } \\
\text { wania }\end{array}$ & $\begin{array}{c}\text { Daty } \\
\text { wojny/po- } \\
\text { wstania }\end{array}$ & Lokalizacja \\
\hline $\begin{array}{l}\text { Stany Zjednoczone } \\
\text { Ameryki }\end{array}$ & Filipińczycy & 1901-1902 & $1899-1902$ & Filipiny \\
\hline Wielka Brytania & Burowie & 1900-1902 & 1899-1902 & Transwal, Orania \\
\hline $\begin{array}{l}\text { Cesarstwo Niemiec- } \\
\text { kie }\end{array}$ & Herero, Nama & 1904-1908 & 1904-1905 & $\begin{array}{l}\text { Niemiecka Afryka } \\
\text { Południowo-Za- } \\
\text { chodnia }\end{array}$ \\
\hline ZSRR & $\begin{array}{l}\text { Rosjanie, Polacy, } \\
\text { Ukraińcy i inne } \\
\text { narody ZSRR }\end{array}$ & 1918-1957 & $\begin{array}{l}1917-1922 \\
1941-1945\end{array}$ & ZSRR \\
\hline Niemcy (III Rzesza) & $\begin{array}{l}\text { Żydzi, Romowie, } \\
\text { Niemcy, Polacy } \\
\text { i inne narody } \\
\text { okupowane }\end{array}$ & 1933-1945 & 1939-1945 & $\begin{array}{l}\text { Niemcy, Austria } \\
\text { i tereny okupo- } \\
\text { wane }\end{array}$ \\
\hline Cesarstwo Japonii & Chińczycy & 1937-1945 & $1937-1945$ & Chiny \\
\hline $\begin{array}{l}\text { Niezależne Państwo } \\
\text { Chorwackie }\end{array}$ & $\begin{array}{l}\text { Żydzi, Romowie, } \\
\text { Serbowie }\end{array}$ & $1941-1945$ & $1941-1945$ & $\begin{array}{l}\text { Niezależne Państwo } \\
\text { Chorwackie }\end{array}$ \\
\hline Francja & Algierczycy & 1954-1962 & 1954-1962 & Algieria (kolonia) \\
\hline Wielka Brytania & Kikuju & $1952-1960$ & $1952-1954$ & Kenia (kolonia) \\
\hline $\begin{array}{l}\text { Demokratyczna } \\
\text { Kampucza (Kam- } \\
\text { bodża) }\end{array}$ & $\begin{array}{l}\text { Khmerzy — „No- } \\
\text { wi Ludzie” i in. }\end{array}$ & 1975-1979 & 1979 & Kambodża \\
\hline Republika Serbska & $\begin{array}{l}\text { Chorwaci, Bosz- } \\
\text { niacy }\end{array}$ & 1992-1995 & 1992-1995 & $\begin{array}{l}\text { Bośnia i Hercegowi- } \\
\text { na }\end{array}$ \\
\hline $\begin{array}{l}\text { Chorwacka Republi- } \\
\text { ka Herceg-Bośni }\end{array}$ & Serbowie & 1992-1995 & 1992-1995 & $\begin{array}{l}\text { Bośnia i Hercegowi- } \\
\text { na }\end{array}$ \\
\hline
\end{tabular}

Źródło: Opracowanie własne.

W socjologii historycznej mamy do czynienia z różnymi metodami porównywania przypadków. Theda Skocpol (1994, s. 72-92) wyróżniła w pracach socjologów trzy logiki rządzące komparatystyką. W swoich badaniach kierowałem się jedną z nich - analizą makroprzyczynową (comparative history as macro-causal analysis), w której poprzez stopniowe, systematyczne porównywanie przypadków wyprowadza się teoretyczne generalizacje. Jest to zatem podejście typowo indukcyjne. 


\section{MASOWA IZOLACJA}

Wszystkie przeanalizowane obozy łączy przymusowa izolacja mas ludności, postrzeganej zgodnie z „logiką kolektywistyczną”. Obozów nie tworzono jako stałych instytucji życia społecznego, które miały funkcjonować obok więzień, pełniąc nowe funkcje (choć mogły działać przez wiele dekad). Postrzegano je jako rozwiązania ekstraordynaryjne, związane z poważnymi wyzwaniami dla społeczności ich organizatorów. Mogła to być wojna międzynarodowa (prowadzona przez Cesarstwo Japonii), wojna partyzancka (Filipiny, Transwal, Orania), czystka etniczna (Niezależne Państwo Chorwackie, Bośnia i Hercegowina), poskromienie zbuntowanych ludów kolonialnych (Niemiecka Afryka Południowo-Zachodnia, Algieria, Kenia), walka z kontrrewolucją (ZSRR) i wrogami politycznymi oraz „rasowymi” (III Rzesza), stworzenie „nowego człowieka” i stosunków społecznych (Kambodża) itd. Zakładano, że wraz z realizacją tego planu społecznego obozy przestaną być potrzebne.

Więźniów obozów, nawet jeśli formalnie zamykano za konkretne przestępstwo, postrzegano jako członków określonej kategorii społecznej, która stanowiła zagrożenie dla społeczności sprawców. Mogła to być ludność cywilna, która zapewniała wyżywienie, schronienie i opiekę medyczną powstańcom (np. Transwal, Orania), osoby zagrażające obyczajności publicznej i kondycji społeczności (np. homoseksualiści w III Rzeszy), wrogowie polityczni (np. ZSRR), byli powstańcy i buntownicy (np. ludność Kikuju w Kenii) czy członkowie wrogiego narodu (np. Chińczycy w obozach japońskich). Obozy były zatem mechanizmem polityki populacyjnej, która stawiała sobie za cel cele makrospołeczne. Uzasadnienia ideologiczne tych projektów (i wzięcia na celownik danej kategorii społecznej) mogły być bardzo różne - od dyskursu Realpolitik, nakazującego postrzegać wszystkich cywilów jako potencjalnych wrogów, niezależnie od ich indywidualnych działań, poprzez dyskurs rasistowski (np. „przestępcy żydowscy” w III Rzeszy), po ideologię komunistyczną, wyróżniającą kategorię kontrrewolucjonistów, którzy pojawiają się wraz z zaostrzeniem walki klasowej.

Bez wątpienia skazanie ludności na izolację wiązało się z postrzeganiem jej jako kategorii osób, które nie korzystają ze wszystkich praw człowieka. W skrajnych przypadkach była to rasistowska dehumanizacja i wyłączenie ofiar „poza świat moralnych zobowiązań” (Fein 1993, s. 36). Ale mogła to też być nieczułość militarnych strategów oraz poczucie wyższości, nakazujące „cywilizować” poddanych mieszkańców. Prezydent Stanów Zjednoczonych William McKinley zauważył: „Nie pozostało nam nic 
innego, jak przejąć Filipiny, ucywilizować ich mieszkańców, wykształcić, nawrócić na chrześcijaństwo i z łaski bożej robić dla nich to, na co nas stać, jak dla ludzi, za których Chrystus oddał życie" (cyt. za: Mularska-Andziak 2006, s. 64). Amerykanie dopuścili się na Filipinach wielu zbrodni (Welch 1974). Ciekawe w tym kontekście są spostrzeżenia afroamerykańskich żołnierzy, którzy sami doświadczali przejawów rasizmu i obserwowali, jak biali Amerykanie traktują Filipińczyków (Russell 2014, s. 206-207).

Izolacja miała różny charakter. Było to następstwo funkcjonowania sieci łączącej ludzi (w tym mieszkających w otoczeniu obozu), zwierzęta (zwłaszcza psy; zob. Kłys 2018), infrastrukturę, krajobraz i klimat. Zamiast drutów kolczastych można było spotkać gęste szeregi ściętych pni akacji, których ciernie miały nawet kilka centymetrów długości, jak w obozie w Windhuku w Afryce Południowo-Zachodniej. W części obozów Gułagu izolację zapewniały ogromne odległości i sroga aura, co sprawiało, że strażnicy mieli ułatwione obowiązki. W komunach wiejskich Demokratycznej Kampuczy izolację zapewniał nieustający nadzór sąsiadów oraz fakt, że zbieg nie miał gdzie się ukryć. Chorwaci i Serbowie wykorzystali istniejące obiekty, przekształcając je w obozy, a ludzi pilnowali żołnierze i członkowie oddziałów paramilitarnych. Niemieckie obozy zaś były wielkimi przedsięwzięciami budowlanymi, wymagającymi skomplikowanej logistyki i wyszkolonych strażników.

W części przypadków obozy spełniły swą rolę, założoną przez sprawców, w innych nie. Generalnie wygrana lub przegrana w wojnie była głównym czynnikiem decydującym o sukcesie twórców obozów. Na przykład Brytyjczycy w Transwalu i Oranii oraz Amerykanie na Filipinach wygrali wojnę partyzancką, a izolacja ludności cywilnej odegrała $\mathrm{w}$ tej walce istotną rolę. Podobnie Cesarstwo Niemieckie ostatecznie poskromiło ludy Herero i Nama (winne jest zresztą ludobójstwa częściowego na tych społecznościach), a Wielka Brytania - Kikujów w Kenii. Z kolei Francuzi musieli wycofać się z Algierii, która uzyskała niepodległość. O klęsce projektów Niemców, Chorwatów i Japończyków zdecydowała przegrana w drugiej wojnie światowej, a o porażce Czerwonych Khmerów klęska $\mathrm{w}$ wojnie $z$ komunistycznym Wietnamem. Chorwaci i Serbowie w Bośni nie zrealizowali swych projektów wielkich republik narodowych pod wpływem interwencji mocarstw (choć przeprowadzono czystki etniczne). Jedynie ZSRR przez dekady skutecznie wykorzystywał Gułag do utrzymywania totalitarnej i autorytarnej władzy, kolonizacji Dalekiego Wschodu i działalności gospodarczej.

Skutki zamknięcia w obozach były bardzo różne. Negatywne są oczywiste, wystarczy wskazać te dotyczące wszystkich przypadków: pozbawienie 
domu rodzinnego, nadzór i kontrolę, głód (wynikający także ze zmiany diety na nieznaną zamkniętej ludności) czy epidemie. Choć trudno doszukiwać się pozytywnych następstw uwięzienia w obozach niemieckich, to w przypadku innych obozów niektórzy autorzy wskazują efekty modernizacyjne. Na przykład Elizabeth van Heyningen (2010) dowiodła, że obozy dla Burów były narzędziem modernizacji tej wiejskiej społeczności. Zwracała uwagę na naukę zasad higieny i żywienia, rozwój infrastruktury, w tym nowe ujęcia wody itd. Oczywiście, taka perspektywa pomija masową śmierć (blisko 30 tys. ofiar; Leśniewski 2006, s. 107), cierpienie ofiar i ich poczucie zdehumanizowania (De Reuck 1999). Podobne dyskusje dotyczyły na przykład obozów w Algierii (Sutton 1977, s. 288-294).

Skupienie dużych mas ludności sprawiało, że nasilało się myślenie w kategoriach biopolitycznych. Wyzwalało je przede wszystkim zagrożenie epidemiami, które mogły dotknąć także strażników. Radzono sobie z nimi w rozmaity sposób. Niemcy, jak wiemy, często posyłali chorych na śmierć. Jednocześnie podejmowali starania, które miały na celu usunięcie pcheł i wszy, acz robiono to albo nieudolnie, albo były to działania, które miały małe znaczenie wobec fatalnych warunków higienicznych, uwarunkowanych ubogą infrastrukturą sanitarną i planem dnia. Kierowali się także uprzedzeniami rasowymi - niemieccy lekarze wierzyli, że epidemia tyfusu zebrałaby znacznie większe żniwo śmierci wśród Niemców niż wśród Żydów, którzy jakoby w dużym stopniu uodpornili się na tę chorobę (Browning 2012, s. 175). Z kolei Anglicy zaangażowali spore siły i środki, aby powstrzymać epidemie w obozach dla Burów. W 1901 roku uwięzieni byli w złej kondycji zdrowotnej i odnotowano wysoką śmiertelność (van Heyningen 2010, s. 3). Sprowadzono zatem nowych lekarzy i pielęgniarki oraz zaangażowano się w leczenie chorób i poprawę higieny. W przypadku obozów nazistowskich i sowieckich mamy do czynienia z nasileniem rasistowskiej biopolityki w rozumieniu Michela Foucaulta (1998, s. 88): „Z jednej strony mamy więc nazistowskie wpisanie rasizmu państwowego w starą legendę wojujących ze sobą ras, a $z$ drugiej strony sowieckie wpisanie walki klas w nieme mechanizmy rasizmu państwowego”. Daje się to też odnieść do komun kambodżańskich, gdyż Czerwoni Khmerzy, wbrew oficjalnej komunistycznej ideologii, kierowali się także rasistowską pogardą, między innymi wobec Wietnamczyków.

\section{WŁADZA I OKRUCIEŃSTWO W OBOZACH}

Obozy stawały się przestrzeniami dominacji, w których funkcjonariusze państwa zamykającego zyskiwali znaczącą władzę. W części obozów 
strażnicy mieli skodyfikowane prawa i obowiązki, związane $z$ eksploatacją, karaniem i torturowaniem więźniów. W innych dzięki swej pozycji mogli dopuszczać się ekscesów, nawet jeśli ich zadaniem miało być możliwie humanitarne przetrzymywanie ludności cywilnej. Jednak w każdym przypadku formalnym działaniom towarzyszyła nieformalna, a nawet nielegalna działalność strażników, którzy mogli realizować swe potrzeby sadystyczne, seksualne czy ekonomiczne. Zgodzić się trzeba z Agambenem (2008b, s. 232-233), że obóz ,jest strukturą, w której stan wyjątkowy - a na decyzji co do jego wprowadzenia opiera się suwerenna władza obowiązuje normalni e”; jest „hybrydą prawa i faktu, w której oba pojęcia stały się nieodróżnialne”.

Zjawiska te nie pojawiały się tylko w odległej przeszłości i dalekich krajach. W czasie wojny w Bośni i Hercegowinie wszystkie strony tworzyły obozy, w których przetrzymywano wrogów, dopuszczając się wobec nich bestialstwa (Markusen 2004, s. 196-197). Znane stały się zwłaszcza obozy serbskie: Omarska (zlokalizowany w byłej kopalnii rudy żelaza), Keraterm (fabryka wyrobów ceramicznych na obrzeżach Prijedoru), Trnopolje, Manjača (Vulliamy 2016, s. 13). Chorwaci prowadzili między innymi obóz w Dretelj („bito tam mężczyzn i gwałcono kobiety”), a Boszniacy w Čelebići na południe od Sarajewa (Vulliamy 2016, s. 62-63). Niejednokrotnie strażnicy i więźniowie znali się wcześniej. Jak zauważył więzień Omarskiej: „Najgorsze było to, że znałem wszystkich strażników i oprawców. Dlatego właśnie nie mogłem zaakceptować, co się ze mną dzieje. [...] Ale kiedy obdarzasz zaufaniem swoich szkolnych kolegów, kumpli z klasy i nauczycieli, a oni zwracają się przeciwko tobie i chcą cię zabić, wtedy cały twój świat rozpada się na kawałki" (Vulliamy 2016, s. 122). Charakterystyczne dla tej wojny były także masowe gwałty, postrzegane jako ważne narzędzie walki z wrogiem (Boose 2002). Rząd bośniacki szacuje, że zgwałcono około 60 tys. kobiet (Drakulić 2006, s. 68) i miało to miejsce także w obozach.

Generalnie postępowanie ze społecznością obozową zależało od tego, czy twórcy obozów stawiali sobie bardziej „ambitne” cele niż tylko izolacja ludności. W obozach, które miały karać i resocjalizować lub wręcz kształtować „nowego człowieka”, występowały intensywne działania strażników i innych nadzorców. Podobnie było w przypadkach, gdy sprawcy planowali przeprowadzić czystkę etniczną lub ludobójstwo częściowe. Postawy wobec więźniów były określane przez uprzedzenia narodowościowe, rasowe i ideologiczne, czasami trudne do uzasadnienia na gruncie dogmatów oficjalnej ideologii. Na przykład choć Czerwoni Khmerzy legitymizowali swe działania ideologią komunistyczną, w kreowanym przez nich dyskursie 
publicznym odnajdujemy wiele elementów rasistowskich, których ofiarą byli zwłaszcza Wietnamczycy, ale także Chińczycy (Etcheson 2004, s. 170; Kiernan 2003, s. 33).

W czasie drugiej wojny światowej obozy satelickiego państwa Chorwatów służyły dwóm celom. Z jednej strony wpisywały się w niemiecką politykę eksterminacji Żydów i Romów, którą ustasze gorliwie popierali, a $z$ drugiej były mechanizmem czystki etnicznej wymierzonej w Serbów i rozwinęły się po tym, gdy Chorwaci byli zmuszeni odstąpić od masowych wypędzeń i masakr, których dopuszczali się na znienawidzonych sąsiadach (Ther 2012, s. 228-232). Ciała okrutnie mordowanych Serbów w obozach nie były spalane $\mathrm{w}$ krematoriach, ale wrzucane do morza lub porzucane na stosach (Korb 2014, s. 113-114). Szeroko znany stał się obóz Jasenovac. O skali nienawiści świadczy charakter mordów. Cywilów palono żywcem, rąbano siekierami, wyłupiano im oczy, kobietom odcinano scyzorykami piersi, a mężczyzn kastrowano. Bez wątpienia w tym przypadku okrucieństwo było także formą zastraszenia wrogiej populacji, a spławiane i porzucane okaleczone ciała pełniły funkcję komunikatów (Korb 2014, s. 117). Ten aspekt komunikacyjny tortur, masakr i okaleczeń możemy zaobserwować w czasie wielu wojen domowych i czystek etnicznych, jak choćby w Bośni i Hercegowinie w latach dziewięćdziesiątych XX wieku (Semelin 2003, s. 368-370).

Podobne zjawisko występowało w obozach, w których przetrzymywano rdzenną ludność kolonii, postrzeganą jako rasowo gorszą i stanowiącą zagrożenie dla kolonistów. Tak było w Afryce Południowo-Zachodniej czy Kenii. W obu przypadkach stworzenie systemu obozów poprzedziły powstania miejscowej ludności. W Kenii stopniowo powstawał system więzień, ośrodków przesłuchań, obozów pracy i koncentracyjnych oraz zamkniętych wsi (które od obozów koncentracyjnych różniły się tylko nazwą; więziono w nich głównie kobiety i dzieci). Zapędzono do nich bezbronnych mieszkańców. Jak szacuje Caroline Elkins (2013, s. 13), pozbawiono wolności około półtora miliona ludzi, czyli prawie całą populację Kikujów. Więźniów obozów i zamkniętych wsi przetrzymywano - najczęściej bez żadnych wyroków — w strasznych warunkach. Zabijano mężczyzn, kobiety i dzieci. Głodzono, pozbawiano wody i opieki medycznej. Gwałcono - i to nie tylko kobiety. Mężczyzn kastrowano. Poddawano wymyślnym torturom (popularną metodą było rażenie prądem i przypalanie). Jeden $z$ dowódców wzięty ranny do niewoli został publicznie spalony żywcem (Pawełczak 2004, s. 193). Pewien kolonista swą gorliwością dorobił się przydomka „Kenijski Joseph Mengele”, a Wydział Specjalny, stosujący masowo tortury, nazywano „kenijskim SS” (Elkins 2013, s. 101, 125). 
Chorwackie okrucieństwo przewyższały praktyki Japończyków, traktujących Chińczyków jako wrogów niższych rasowo. Znane są powszechnie opisy złego traktowania zachodnich jeńców w japońskich obozach w czasie drugiej wojny światowej, ale Chińczycy wcześniej padli ofiarą japońskiej agresji i - jeśli nie zamordowano ich od razu - traktowano ich $\mathrm{z}$ wyjątkowym bestialstwem. Było to pochodną wojny totalnej w Chinach. W latach 1941-1942 pacyfikacja chińskiej prowincji zamieniła się w taktykę spalonej ziemi (Dower 1993, s. 43). Japończycy brutalnie traktowali zresztą wszystkich Azjatów, mimo retoryki walki z kolonializmem białego człowieka. Powszechnie stosowano tortury także poza obozami; kobiety zaś zamieniane były w niewolnice seksualne (Dower 1993, s. 46-47).

Kambodżańskie komuny (najbardziej odległe od potocznego wyobrażenia obozu koncentracyjnego) były miejscem tworzenia nowego, autarkicznego społeczeństwa chłopów (Jelonek 1999). Wymagało to eksterminacji wrogów i reedukacji podejrzanych. Czerwoni Khmerzy na celownik wzięli nie tylko mniejszości etniczne i religijne (Wietnamczyków, Czamów, Chińczyków, Laotańczyków i Tajów) oraz mnichów buddyjskich, ale również etnicznych Khmerów (stąd pojęcie „autoludobójstwa”). Kluczowy okazał się podział na ludzi „Starych” i „Nowych”. Ci pierwsi (multethan) pochodzili z regionów, które na długo przed końcem wojny domowej znajdowały się pod panowaniem komunistów. Ci drudzy (bennheu), zwani też „ludźmi 17 kwietnia” (tego dnia w 1975 roku Czerwoni Khmerzy wkroczyli do stolicy), zamieszkiwali enklawy, które najdłużej pozostawały pod władzą Lon Nola (generała i prezydenta, który zdobył władzę w wyniku zamachu stanu; zob. Jelonek 2008, s. 153-154). Także mieszkańcy miast, postrzeganych jako siedliska zepsucia i zagranicznych wpływów, zostali wypędzeni i zagnani do komun. Podobny los spotkał studentów i osoby wykształcone. Byli oni poddani drakońskiej dyscyplinie, wyczerpującej pracy i karani za najmniejsze przewinienia. Często padali też ofiarą mordów. Okrucieństwu sprzyjała tradycyjna kultura zemsty. Inaczej niż w przypadku biblijnej zasady „oko za oko”, Khmerzy posługiwali się koncepcją nieproporcjonalnej zemsty, którą Alexander Laban Hinton (1998, s. 353) ujął w maksymę „głowa za oko".

Wypędzenie Khmerów z miast i zamknięcie ich w komunach, w których podlegali totalitarnemu nadzorowi (którego nie udało się osiągnąć na poziomie państwa) pozwala postrzegać komuny jako obozy koncentracyjne, choć sytuacja w nich była bardzo zróżnicowana. Obok zwykłych kooperatyw istniały obozy reedukacyjne, $\mathrm{w}$ których panowały cięższe warunki pracy (Jelonek 1999, s. 147). Okrucieństwa i mordy nie były jedynie następstwem lokalnej wersji „kolektywizacji”, ale wynikiem wcielania 
w życie utopijnego projektu społecznego. Władze centralne w Demokratycznej Kampuczy pozostawały słabe, co sprawiało, że znaczną władzę (także w zakresie interpretacji partyjnych zaleceń) zyskiwali lokalni zarządcy (Jelonek 1999, s. 75). Pamiętać też trzeba, że niektóre cierpienia Khmerów były wynikiem $z$ założenia postępowych zmian, na przykład praktycznego szkolenia lekarzy (w tym chirurgów) poprzez leczenie, a nie abstrakcyjną edukację. Relacje w komunach określało nowe środowisko gospodarcze, w którym zakazano pieniędzy i prywatnej własności (poza miską i łyżką), a podstawą uzupełniania deficytów był (formalnie nielegalny) barter. Czerwoni Khmerzy często stosowali metaforykę agrarną opisując walkę z wrogami, których ciała miały użyźnić chłopską ziemię (Kiernan 2007, s. 547).

$\mathrm{Na}$ tym tle obozy niemieckie i sowieckie odznaczały się złożonością i gęstością relacji władzy. Gułag (właśc. GUŁag; Gławnoje Uprawlenije Łagieriej i Raboczich Posielenij - Główny Zarząd Obozów i Osiedli Pracy) był złożonym systemem, który zmieniał się w czasie. Oprócz więźniów obejmował także specprzesiedleńców (zesłańców). Już w sierpniu 1918 roku na rozkaz Lenina utworzono obozy koncentracyjne (jak je wówczas nazywano) dla buntujących się chłopów, popów i białogwardyjskich oficerów ${ }^{1}$. W końcu 1919 roku było 21 obozów, a w 1922 roku już 132 (Kalbarczyk 2009, s. 12). W 1923 roku utworzono Sołowiecki Obóz Prac Przymusowych Specjalnego Przeznaczenia (w Archangielsku i Komi), przeznaczony dla najgroźniejszych „przestępców państwowych”. Niektórzy uznają go za pierwszy właściwy obóz prac przymusowych (Kalbarczyk 2009, s. 13). Kolejna zmiana nastąpiła w 1929 roku. Obozy stały się instrumentami planowej gospodarki sowieckiej (Khlevnyuk 2001, s. 113). Doprowadziło to do lawinowego rozrostu sieci obozów - w 1929 roku było około 22 tys. więźniów, a w 1934 już ponad pół miliona (Kalbarczyk 2009, s. 14). Największy strumień więźniów napłynął jednak w wyniku Wielkiej Czystki. W latach 1940-1941 zmieniła się struktura Gułagu — powstały wyspecjalizowane Zarządy, zajmujące się wydzielonymi formami aktywności gospodarczej. Tym samym Gułag stał się „czymś w rodzaju przedsiębiorstwa" (Kalbarczyk 2009, s. 18). W 1943 roku utworzono obozy katorżne przeznaczone dla „niemiecko-faszystowskich złoczyńców, szpiegów, zdrajców ojczyzny i ich współpracowników". Liczba katorżników wzrosła z 6 tys. w roku 1944 do 60 tys. w 1947. W 1945 roku ogłoszono masową amnestię, zwalniając ponad milion więźniów kryminalnych, co

${ }^{1}$ Oczywiście, można także wskazać wcześniejsze strategie masowych deportacji i czystek etnicznych w Imperium Rosyjskim; zob. Werth 2010, s. 386-391. 
wywołało poważne zaburzenia w systemie obozów (Alexopoulos 2005). W 1948 roku utworzono obozy specjalne, w których zamykano „szczególnie niebezpiecznych przestępców państwowych", często doświadczonych żołnierzy. W 1952 roku łączna liczba osadzonych w tych obozach wynosiła 250 tys. (Kalbarczyk 2009, s. 19-22). Między rokiem 1929 a 1953 istniało 476 kompleksów obozowych; każdy z nich składał się dziesiątek lub setek łagpunktów (Applebaum 2005, s. 189). W 1957 roku Główny Zarząd Obozów i Osiedli Pracy zlikwidowano.

Ten pobieżny przegląd pokazuje, że w przypadku Gułagu nie da się mówić tylko o jednym typie obozu, podobnie zresztą jak w przypadku systemu obozów niemieckich. Warunki życia uwięzionych zależały od postawy oraz charakteru komendanta i bardzo się różniły (Applebaum 2005, s. 189-190). Widać jednak, że dominowały obozy, które były nastawione na eksploatację siły roboczej, niezależnie od deklarowanych celów Gułagu. Nie znaczy to, że nie eksterminowano określonych kategorii społecznych - nie wykorzystywano jednak do tego systemu obozów, lecz inne metody, przede wszystkim masowe rozstrzelania (Mann 2006, s. 321-330). Na przykład liczba zabitych w czasie operacji przeciw kułakom (1937-1938) mniej więcej zrównała się z liczbą wysłanych do Gułagu (odpowiednio 378326 i 389 070; Snyder 2011, s. 107). Więźniowie dzielili się na tych, którzy zostali skazani na poniżej i powyżej pięciu lat oraz na skazanych za „przestępstwo kontrrewolucyjne” (Kalbarczyk 2009, s. 17). Wyśrubowane normy określały sposób traktowania więźnia, w tym normy kaloryczne.

W porównaniu z obozami niemieckimi obozy w ZSRR mogą sprawiać wrażenie instytucji anarchistycznych. Wielu więźniów miało dużą swobodę poruszania się bez nadzoru, regulamin często łamano, strażnicy nie interweniowali w przypadku aktów przemocy, okrucieństwa i gwałtów jednych więźniów na drugich (Applebaum 2005, s. 193-195). W obozach sowieckich znaczącą rolę odgrywali więźniowie kryminalni. Podobnie było w obozach niemieckich, zwłaszcza na początku ich funkcjonowania, ale w ZSRR władza kryminalistów była bez porównania większa. Niemcy wykorzystywali kryminalistów jako więźniów funkcyjnych, wpisanych W strukturę obozową; Sowieci musieli się zmagać z walkami różnych grup więźniów kryminalnych i politycznych, a także z buntami.

W obozach specjalnych więźniów uważnie pilnowano i poddano drakońskiej dyscyplinie. Początkowo zorganizowano pięć takich obozów, ale do 1 lipca 1951 r. było ich już dziesięć (Rogut 2010, s. 275-276). Znalazło się w nich wielu Ukraińców i mieszkańców republik nadbałtyckich. Szczegółowe rozkazy dotyczące przetrzymywania więźniów w praktyce trudno 
było wykonać, ale osadzeni poddani byli o wiele ściślejszemu nadzorowi niż w innych obozach. Mimo ciężkich warunków życia i systemu kar również obozy specjalne nie mogą być uznane za „obozy śmierci”. Widać także odmienne od Niemców podejście Sowietów do więźniów. Gdy wybuchło „powstanie kengirskie” (17 maja 1954 r.) negocjowano z buntownikami, w czasie zbrojnej pacyfikacji podobozu zabito tylko 37 osób, a później przywódców osądzono (Rogut 2010, s. 288-291).

$\mathrm{Na}$ tym tle ujawnia się bezprecedensowość systemu obozów niemieckich. Zasoby władzy funkcjonariuszy nazistowskich zostały pomnożone $\mathrm{w}$ najwyższym stopniu. W niemieckich obozach doszło więc do zmiany jakościowej, gdyż — za Wolfgangiem Sofskym (2016, s. 28) — można mówić o występującej w nich władzy absolutnej. Czym jest władza absolutna? Uwalnia ona przemoc od wszelkich zahamowań i potęguje przez zorganizowane działanie. Choć łączy w sobie niektóre elementy i metody tradycyjnych typów władzy, to stanowi formę odrębną. Można wskazać dziesięć jej głównych cech (Sofsky 2016, s. 29-39). Po pierwsze, jest władzą zorganizowaną, przy czym formalne reguły jej nie ograniczają (w obozie „stanowiły instytucjonalną podbudowę dla swobody terroru”). Po drugie, jest to władza absolutnego etykietowania. To sprawcy tworzą i narzucają ofiarom przynależność do określonych kategorii społecznych. Po trzecie, jest to władza ustopniowana, czyli oparta na wymyślnym systemie kolaboracji. W obozie byli więźniowie funkcyjni, którzy — jak twierdzi Sofsky — wzmacniali władzę SS-manów. Po czwarte, władza absolutna obywa się bez ideologicznego uprawomocnienia. „Władza, która musi się uprawomocniać, to słaba władza" - podkreśla autor. Po piąte, władza ta zmienia sens pracy ludzkiej. Choć Sofsky wskazuje także pragmatyczne cele, którym służył system obozowy, to według niego obozowa gospodarka była „ekonomią marnowania ludzkiej siły roboczej”. Jak bowiem podkreśla, terror „nie dąży do wyzysku, jego celem jest upadek, cierpienie, destrukcja jako taka". Po szóste, jest to władza całkowita, znosząca symetrię przemocy. Poddany jej człowiek jest całkowicie bezbronny, nawet samobójstwo nie jest tolerowane. Po siódme, manifestuje się najbardziej bezpośrednio w nagiej przemocy. Zbrodnia i okrucieństwo są jej esencją. Po ósme, powoduje absolutną bezsilność. Każdy czyn może stać się pretekstem do zabójstwa, każda reguła może być zmieniona na niekorzyść więźnia. Tym samym „już samo przeżycie jest aktem sprzeciwu”. Po dziewiąte, „zaciera linię demarkacyjną dzielącą życie od śmierci", czego symbolem staje się obozowy „muzułman”. Wreszcie władza absolutna „dąży do potęgowania samej siebie". Osiąga swój cel wtedy, gdy nie musi się już liczyć z żadnymi wyjątkami. 
Sofsky opisuje przestrzeń i czas nie tylko jako ramy i warunki możliwości działania władzy absolutnej, ale również jako przedmioty jej wpływu. Niszczy ona bowiem przestrzeń ,jako przestrzeń działania i życia” (Sofsky 2016, s. 65), zamieniając ją w swoje medium. Sofsky analizuje przeto przestrzenną strukturę obozu, ujawniając nie tylko jej potencjał dyscyplinarny, ale przede wszystkim wpływ na organizację terroru: „Dla dawnej władzy dyscyplinarnej przestrzeń była środkiem tresury i obserwacji. Dla władzy absolutnej jest narzędziem społecznej dyskryminacji i śmierci" (Sofsky 2016, s. 74). Co ważne, z jednej strony narzucano reguły przestrzennego ładu, za łamanie których brutalnie karano, a z drugiej nieustannie wytwarzano chaos, który umożliwiał intensyfikację terroru. Patologiczne zagęszczenie nie tylko zmieniało ludzi, ale również ułatwiało kontrolę bez stosowania nieustannej przemocy. Również czas został skolonizowany przez władzę absolutną. Rozbijała ona „wewnętrzną więź pamięci, oczekiwania i nadziei” u więźniów (Sofsky 2016, s. 96), ale także niszcząc tradycyjne sposoby organizacji czasu - na przykład przez zakaz noszenia zegarków - potęgowała cierpienie. Strażnicy zawsze mieli czas i nie musieli się śpieszyć - więźniowie zaś byli ciągnącym się czasem dręczeni i uśmiercani, jak w przypadku „apeli eksterminacyjnych".

Rekonstruując zasady administracyjne SS Sofsky pokazuje wielość układów oddalających obozową praktykę od tej panującej w organizacjach formalnych. Esesmani bronili swoich towarzyszy przed nadzorem nie tylko zewnętrznych instancji, ale także kontrolerów z SS. To kumoterstwo i osobista inicjatywa, a nie sprawna biurokracja zapewniały morderczą skuteczność systemu obozów. „Terror potrzebuje struktur, które unieważniają formalne reguły i ograniczenia stosunków bezosobowych" (Sofsky 2016, s. 135). Totalna nadregulacja nie generowała ładu, ale nieład, zapewniający strażnikom dodatkową władzę.

Szczególną uwagę poświęca Sofsky obozowym klasyfikacjom, które były bardziej złożone, niż wskazywał na to system „winkli”. Wskazuje na cztery hierarchicznie uporządkowane kryteria: (1) rasistowski podział na ludzi i „podludzi”; (2) hierarchię narodowości; (3) kryteria wrogości politycznej i (4) dewiacji społecznej. Pozwala mu to opracować system klasyfikacji wyznaczający prawdopodobieństwo przeżycia. Oczywiście, system ten nie był statyczny. Decydował nie tylko o władzy, ale także o pracy i posiadaniu. Wiązał się także z dystrybucją kapitału społecznego. Więźniowie $\mathrm{w}$ znacznej mierze przejmowali system kategorii narzucony przez SS, co wzmacniało terror. Dopiero wraz z ekonomizacją ich pracy w dwóch ostatnich latach wojny ten system kategorii stracił na znaczeniu. Kategoria 
więźniów „asocjalnych” pokazuje, w jakim stopniu obozy koncentracyjne były nie tylko narzędziem walki politycznej, ale także odnowy „rasy aryjskiej" i społeczeństwa niemieckiego. Widać to choćby w postępowaniu z prostytutkami (zob. Harris 2010).

Sofsky analizuje także różne formy przemocy, eksterminacji i masowej śmierci w obozie. Odwołuje się do figury „muzułmana” — skrajnie wycieńczonego więźnia na skraju śmierci, który „ucieleśnia w wyjątkowo radykalnej formie antropologiczne znaczenie władzy absolutnej" (Sofsky 2016, s. 262). W rozważaniach tych znajdujemy wiele podobieństw do cyklu Homo sacer Agambena (2008a). Szczególną uwagę trzeba poświęcić karom i torturom w obozach (Strzelecka 1995). Sofsky rozpatruje je nie w perspektywie dyscyplinarnej, ale systemu terroru. „Władza absolutna wyzbywa się przepisów, przekształca karę i toruje drogę ekscesywnemu okrucieństwu. Przedmiotem poniższych badań są zatem procedury i sytuacje, które zmieniają sankcje w terror" (Sofsky 2016, s. 281). Prowadzi go to wprost do zajęcia się ekscesami władzy — zagadnieniem, które systematycznie porusza w swoich książkach (zob. Sofsky 1999). W ekscesie bezbronny pada ofiarą dysponenta władzy, który daje wyraz swej wszechmocy. Okrucieństwa nie należy traktować jako ślepego wybuchu nienawiści i ekspresji sadyzmu. Warunkiem wyzwolenia okrucieństwa jest dla Sofsky'ego instytucjonalizacja terroru, która umożliwiała podział pracy w zakresie stosowania przemocy. Stosowanie kaźni określała też struktura społeczności strażników (którzy sami przechodzili brutalne szkolenie), w której demonstracyjne ekscesy budziły szacunek i uznanie. Swobodę strażników zwiększało rozproszenie odpowiedzialności. Nie miejsce tu na mnożenie przykładów okrucieństwa, przywołam zatem tylko jeden z nich z obozu Stutthof, pokazujący sadystyczną wyobraźnię strażników. Jak zanotował duński więzień: „Zarówno «zieloni», jak i SS-mani zabawiali się tresowaniem chłopców tak jak tresuje się psy strażnicze. Szczuli ich i uczyli rzucać się na starych, umierających więźniów jak stado wilków, wyrywać im jedzenie, odbierać buty, czapki oraz zabijać" (cyt. za: Grabowska 1977, s. 49).

Niemiecki obóz koncentracyjny był także przestrzenią seksualnej eksploatacji i przemocy. W obozach kobiety zmuszano do pracy w domach publicznych. Pierwszą taką instytucję stworzono w czerwcu 1942 roku w obozie Mauthausen. Także w Oświęcimiu powstały „puffy” — seksualne robotnice do obozów Auschwitz I i Auschwitz III rekrutowano w Birkenau. Zakładano, że jako nagroda za wydajną pracę będą one motywowały więźniów do zwiększonego wysiłku (Ostrowska 2018, s. 137-173). Wykorzystywano także mężczyzn. W obozie istniała instytucja „pipla”, czyli 
służących więźniom funkcyjnym chłopców i młodych mężczyzn, którzy często musieli świadczyć swoim panom także usługi seksualne (Heger 2016). Również w tym wymiarze niemieckie obozy okazały się bezprecedensowym miejscem wielowymiarowej seksualnej eksploatacji.

O władzy i dominacji w obozach świadczą także samobójstwa wśród więźniów. Oczywiście, liczba samobójstw rośnie w czasie wojen, rewolucji czy innych przypadków zaburzeń porządku publicznego, ale w obozach samobójstwa były nie tylko indywidualnymi decyzjami złamanych ludzi. Dotyczy to zwłaszcza obozów niemieckich, w których liczba samobójstw — jak się szacuje - była 10-30 razy wyższa niż w całej populacji; była także wyższa niż w obozach sowieckich (López-Muñoz, Cuerda-Galindo 2016, s. 2). Trzeba pamiętać, że badaczom brakuje rzetelnych danych - strażnicy nie odnotowywali przypadków samobójstw, dokumenty są niekompletne, gdyż wiele $z$ nich zniszczono pod koniec wojny, strażnicy ukrywali morderstwa, przedstawiając je jako samobójstwa itd. Można jednak zauważyć, że były to różnego typu samobójstwa w rozumieniu Émile’a Durkheima (2006). Więźniowie polityczni popełniali samobójstwa altruistyczne, chcąc uniknąć zdradzenia towarzyszy w czasie tortur. Wielu więźniów pozbawionych poczucia sprawczości uciekało się do samobójstwa fatalistycznego. Co ważne, w przypadku obozu był to akt sprzeciwu wobec wszechmocy sprawców wyposażonych we władzę absolutną. Popełniając samobójstwo więźniowie rzucali wyzwanie władzy i dowodzili swej podmiotowości, unikając także stoczenia się na pozycje „muzułmanów”. Jednocześnie trzeba jednak pamiętać, że — jak zauważył Terrence Des Pres (1980, s. 100) - luksus poświęcenia był bez znaczenia w świecie, w którym każda śmierć tylko wzmacniała sukces zła.

\section{EKONOMIA NIEWOLNIKÓW}

Obozy wymagały nakładów finansowych, a ich organizatorzy na różne sposoby starali się oszczędzać. Mogło to polegać na obniżaniu kaloryczności racji żywnościowych i odmawianiu zaspokajania różnych potrzeb więźniów, na grabieży lub wykorzystaniu przymusowej pracy osadzonych. W rozwiniętych systemach obozowych obok obozów koncentracyjnych tworzono obozy pracy, ale granica między nimi nie była wyraźna. Wystarczy przypomnieć, że podobóz kompleksu Auschwitz - Monowitz (od listopada 1943 roku obóz koncentracyjny) powstał jako zaplecze dla obiektów przemysłowych IG Farben. Obozy Gułagu od początku miały być samowystarczalne; z czasem zakładano, że staną się ważną częścią centralnie planowanej gospodarki. 
Niemiecki przypadek pokazuje rolę zmiennego kontekstu. Przeciąganie się wojny na wschodzie sprawiło, że Niemcy cierpieli na coraz większe braki siły roboczej, co zmieniło spojrzenie na więźniów obozów koncentracyjnych. Było to jednak pochodną rasistowskiej polityki okupacyjnej, w myśl której zamknięci w obozach od początku postrzegani byli jako przedmiot służący zaspokajaniu dowolnych potrzeb nazistów.

Odmiennie było w koloniach osadniczych, gdzie rdzennych mieszkańców postrzegano jako rasowo niższych (zauważmy przy okazji, że Burowie, choć zamknięci w obozach, byli potomkami białych europejskich osadników; i że często zapomina się o cierpieniach ludności czarnoskórej i obozach dla autochtonów; De Reuck 1999, s. 70-71). Tam mimo pogardy dla miejscowej ludności, postrzegano ją jako zasób siły roboczej, która zwalniała kolonistów z wielu uciążliwych prac. W niemieckiej kolonii w dzisiejszej Namibii, mimo częściowego ludobójstwa, przymusowa praca została zintensyfikowana dzięki systemowi obozów. Ustanowiono tak ciężki reżim dla Hererów i Nama, że „można go uważać za ciąg dalszy ich eksterminacji" (Olusoga, Erichsen 2012, s. 273). Po zamknięciu obozów w 1908 roku więźniów pozostałych przy życiu przydzielono niemieckim osadnikom jako niewolników.

Kolonie różniły się nie tylko rodzajem politycznej podległości metropolii, ale także modelami gospodarczymi. Tam, gdzie ludność miejscowa była zbędna i stanowiła konkurenta do ziemi i zasobów, często dochodziło do masowych masakr, a nawet ludobójstw, co zgodne było z logiką kapitalizmu. Jak zauważył Erik O. Wright (2006, s. 814) — ludobójstwo jest „zawsze potencjalną strategią dla uciskających, którzy nie posługują się wyzyskiem. Nie wchodzi to w grę w sytuacji wyzysku ekonomicznego, ponieważ wyzyskiwacze potrzebują pracy wyzyskiwanych, aby zapewnić sobie materialne powodzenie". $Z$ kolei przydatność autochtonów do akumulacji kapitału kolonistów sprawiała, że wykorzystywano ich jako przymusową siłę roboczą (Mann 2006, s. 71-72). Tam, gdzie potrzebna była skoncentrowana siła robocza (kopalnie, plantacje), powstawały instytucje wyzysku, które nieraz mogłyby być uznane za obozy koncentracyjne. Pomyślane przy tym były jako instytucje trwałe - przypominały w tym sensie Gułag.

Dylemat eksterminacja-zniewolenie występował nie tylko w koloniach. W czasie drugiej wojny światowej przedsiębiorcy lub oficerowie Wehrmachtu czerpiący zyski z niewolniczej pracy Żydów niejednokrotnie musieli być zmuszani do wydawania pracowników na rzeź (Libionka 2017, s. 187-189). Dylemat ten jest zresztą typowy dla ludobójstwa, w przypadku gdy dążenie do anihilacji całej kategorii społecznej prowadzi do sytuacji nie tylko korzystnych dla sprawców (opustoszałe nisze gospodarcze, za- 
grabione mienie do redystrybucji itp.), ale również negatywnych (brak rąk do pracy, niedostatek specjalistów itp.).

W ZSRR Gułag od lat trzydziestych postrzegano jako źródło produktu narodowego. Szczególne znaczenie miał Kanał Białomorsko-Bałtycki, zbudowany w ekspresowym tempie w latach 1930-1933, który dowodził w praktyce „zaawansowania” ekonomii obozowej. I nie ma tu znaczenia to, że wielu założeń tej inwestycji nie udało się zrealizować. Rdzeniem Gułagu były wielkie projekty, realizowane $z$ wykorzystaniem przymusowej pracy więźniów (Khlevnyuk 2001, s. 115). W praktyce jednak gospodarka Gułagu była oparta na marnotrawstwie. Masowa śmierć więźniów i niewłaściwe wykorzystanie specjalistów w obozach uderzało w cały system. Zyski (np. z wydobycia minerałów) osiągano dzięki drapieżnej eksploatacji środowiska. Nie eksploatowano intensywnie parku maszynowego. Gułag $z$ tanią siłą roboczą miał także niekorzystny wpływ na cały rynek pracy w ZSRR; praca więźniów działała na sowiecką gospodarkę jak narkotyk (Khlevnyuk 2001, s. 125-128).

Niewolnicy - ocaleni więźniowie nazistowskich obozów często mówili o sobie w ten sposób. Jednak systematyczną weryfikację tej analogii przeprowadziło niewielu badaczy (m.in. Stanley Elkins, Claus Füllberg-Stolberg, Wolfgang Sofsky czy Andrzej Kamiński). Przede wszystkim trzeba pamiętać, że niewolnictwo można zdefiniować na różne sposoby, a jego historyczne formy bardzo się różniły. Marc Buggeln (2008) porównał przymusową pracę $\mathrm{w}$ niemieckich obozach koncentracyjnych $\mathrm{z}$ pracą niewolników na plantacjach na południu Stanów Zjednoczonych. Według niego istnieje wiele podobieństw: $\mathrm{w}$ obu systemach dehumanizacja więźniów zaczynała się wraz z pojmaniem i transportem; więźniowie byli odcinani od swojego środowiska społecznego; strażnicy i nadzorcy obawiali się buntu i wprowadzali ścisły nadzór; powstawały napięcia i konflikty między nadzorem a gospodarczym wykorzystaniem siły roboczej; wykluczenie niewolników ze społeczeństwa uzasadniane było ideologicznie (Buggeln 2008, s. 108-112). Występowały też poważne różnice: w Stanach Zjednoczonych nie było planów systematycznej eksterminacji czarnoskórych, w obozach zaś poziom codziennej przemocy i śmiertelności był znacznie wyższy; ponadto niewolnictwo na amerykańskim Południu pomyślane było jako rozwiązanie stałe, a niemieckie wykorzystanie pracy przymusowej jako rozwiązanie na czas wojny (Buggeln 2008, s. 112-113, 125). Te różnice są fundamentalne, gdyż w systemie niewolniczym, choć zdarzały się brutalne kary, tortury i morderstwa, niewolnik był cennym zasobem. W obozach nazistowskich nawet więźniowie, którzy swą pracą służyli wysiłkowi wojennemu lub zapewniali SS dochody, byli traktowani bardzo 
źle i z łatwością zabijani. Nie ulega przy tym wątpliwości, że praca przymusowa - mimo wszystkich patologii — była ważną funkcją obozów w III Rzeszy. Analogia z niewolnictwem o wiele lepiej pasuje do przypadków systemów obozów kolonialnych.

Bez wątpienia efektywność obozów jako źródła siły roboczej była związana $z$ modelem gospodarki. Praca fizyczna nie wymagająca kwalifikacji miała duże znaczenie w gospodarce przedfordowskiej i fordowskiej, zwłaszcza w czasie toczącej się wojny. Powołanie do wojska obywateli powodowało poważne braki na rynku pracy, zwłaszcza w czasie wojen totalnych. Jak długo opłacalne było niewolnictwo, tak długo również koncentracja ludności i zmuszenie jej do pracy pozwalały akumulować kapitał. W gospodarkach kolonialnych ta zależność utrzymała się znacznie dłużej, co wynikało $z$ uzależnienia ekonomicznego kolonii od metropolii oraz postrzegania kolonialnej hegemonii jako źródła międzynarodowej pozycji i prestiżu. Podobnie jak niewolnictwo, obozy pracy przymusowej mogły też odwlekać reformę rynku pracy. Sytuację ekonomiczną zmieniała także presja wojenna, która miała wpływ na wolnorynkowy rachunek zysków i strat. Co ważne, w przypadku analizowanych obozów podmiotem wykorzystującym przymusową pracę więźniów było państwo, nawet jeśli współpracowano z prywatnymi przedsiębiorstwami. Organizowane przez państwo niewolnictwo było częstym fenomenem w latach 1880 -1960 (Buggeln 2008, s. 127) - z tej perspektywy trzeba spojrzeć także na przymusową pracę w obozach.

Nie ulega wątpliwości, że obozy koncentracyjne generalnie nie były przede wszystkim obozami pracy, nawet jeśli część sprawców tak postrzegała ich rolę. Wykorzystywanie więźniów było pochodną strategii militarnej i politycznej. Obozy miały pomóc wygrać wojnę, spacyfikować opozycję, stworzyć posłusznych obywateli i zapewnić elitom szeroki zakres władzy.

\section{PODŁE CIAŁA}

Niektóre obozy stawały się źródłem nie tylko niewolniczej siły roboczej, ale również obiektów do eksperymentów medycznych i pseudomedycznych oraz ciał i ich części na potrzeby badań i dydaktyki. W tym zakresie obozy wpisały się $\mathrm{w}$ sięgający w odległą przeszłość nurt wykorzystywania ciał skazańców, więźniów i innych osób postrzeganych jako mało wartościowe (Chamayou 2012). Najlepiej znany jest naturalnie przypadek obozów niemieckich, w którym nie tylko szarlatani, ale również lekarze i naukowcy o uznanej pozycji przeprowadzali zbrodnicze ekspe- 
rymenty medyczne i antropologiczne (zob. Schafft 2006, s. 141-160; Klee 2005). Obejmowały one badania nad malarią, zwalczaniem szkodników, posocznicą, gruźlicą, toksyczną amunicją, odtruwaniem, śmiercią na dużych wysokościach, $\mathrm{z}$ wychłodzenia, sterylizacją — i wieloma innymi zagadnieniami. Eksperymentowano także na dzieciach (np. badania w komorze podciśnień; Klee 2005, s. 220-223).

Jednak z tego typu przypadkami mieliśmy do czynienia także gdzie indziej. W Niemieckiej Afryce Południowo-Zachodniej więźniowie obozów byli wykorzystywani jako „materiał biologiczny”. Część ciał ofiar obozu na Shark Island służyła jako materiał do badań medycznych i rasowych. Rozwinął się wręcz cały „przemysł” związany z częściami ciał — w 1905 roku w obozie Swakopmund więźniarki zmuszono do gotowania odciętych głów i oskrobywania ich z tkanki i ścięgien. Wysyłano je do niemieckich muzeów, prywatnych kolekcji i zbiorów uniwersyteckich. Eksperymentowano także na więźniach. Doktor Bofinger prowadził badania nad szkorbutem - błędnie uważał, że to choroba zakaźna (Olusoga, Erichsen 2012, s. 299-303).

Eksperymenty medyczne na więźniach przeprowadzali także Japończycy. Najbardziej znana jest Jednostka 731 (utworzona już w 1932 roku w Mandżukuo - satelickim państwie powstałym na terenie okupowanej Mandżurii w północno-wschodnich Chinach), w której prowadzono badania nad nowymi rodzajami broni biologicznej i chemicznej (McCormack 2003, s. 282). Z więźniów uczyniono zwierzęta doświadczalne. Szacuje się, że ponad tysiąc jeńców zginęło w eksperymentach dotyczących wąglika, zatrucia jadem kiełbasianym, brucelozy, cholery, czerwonki, zgorzeli gazowej, infekcji meningokokowej i dżumy (Eitzen, Takafuji 1997, s. 417).

Również Gułag stał się miejscem eksperymentów - i to w dwojakim sensie. Uwięzieni naukowcy - w relatywnie dobrych warunkach - począwszy od 1929 roku realizowali zadania badawcze zlecone przez władze ( $w$ tym $w$ ramach programu atomowego). Przeprowadzano również obserwacje i eksperymenty medyczne na więźniach obozów. Wiele z tych badań zrealizowano w czasie wojny. Poświęcone były chorobom, które nękały zarówno więźniów, jak i populacje cywilne, takim jak szkorbut, dystrofia żywieniowa, pelagra, tyfus i gruźlica. Uważnie badano skutki niedoboru witamin i chorobę głodową (Alexopoulos 2016, s. 365). Naukowcy często ukrywali, że źródłem patologicznych stanów jest poziom życia w obozie; zamiast tego pisali na przykład o czynnikach klimatycznych. Generalnie, choć w Gułagu zbrodniczych eksperymentów na ludziach nie przeprowadzano na taką skalę jak $\mathrm{w}$ niemieckich obozach, to naukowcy i lekarze musieli dostosować się do porządku obozowego, zarówno w języku rapor- 
tów, jak i zainteresowaniach badawczych oraz zaleceniach. Dlatego personel uczono rozpoznawać samookaleczenia, przemilczano głodowe racje czy zalecano dawki leków pozwalające na oszczędności budżetowe (Alexopoulos 2016, s. 378-381). Tym samym większość lekarzy włączała się w stalinowską praktykę kryminalizowania chorych więźniów.

Eksperymentowanie na ludziach w latach 1933-1945 było związane nie tylko $z$ totalitarnymi reżimami w Niemczech i Japonii. Był to wynik istnienia ścieżki głębokiej zależności, której przejawy odnajdujemy także w krajach demokratycznych (szerzej zob. Baader i in. 2005). Działania dziś postrzegane jako zbrodnie medyczne mogły być uznawane za dopuszczalny mechanizm polityki społecznej. Na przykład w Stanach Zjednoczonych w latach 1899-1945 wysterylizowano ponad 45 tys. osób. W latach 1907-1921 wykonano też 3233 sterylizacje na osobach przebywających w instytucjach zamkniętych (Musielak 2008, s. 142). Amerykanie nie prowadzili jednak systemowych eksperymentów na więźniach obozów (choć dopuszczali je na przykład w ośrodkach zamkniętych; wystarczy przypomnieć badania nad Afroamerykanami zarażonymi syfilisem w Tuskegee).

Choć funkcja ta była realizowana tylko w niewielu przypadkach, to potwierdza to zasadniczy charakter obozów jako przestrzeni stanu wyjątkowego, w której ludzie postrzegani jako gorsi stawali się biologiczną masą. Trzeba ją było utrzymywać przy życiu, ale także dyscyplinować, represjonować i wykorzystywać. Oczywiście, ludzi wbrew ich woli wykorzystywano także w tajnych projektach badawczych, realizowanych niezależnie od obozów. Obozy tworzyły jednak zarazem pokusę i szansę dla badaczy, którzy niekoniecznie zajmowali wysoką pozycję w polu naukowym.

\section{PODSUMOWANIE}

Pod nazwą obozu koncentracyjnego kryją się bardzo różne urządzenia społeczne. Jak widać, obozy zakładały zarówno państwa totalitarne (III Rzesza, stalinowskie ZSRR), jak i demokratyczne (Stany Zjednoczone, Wielka Brytania). Niemieckie nazistowskie obozy koncentracyjne stały się jednak instytucjami bez precedensu, w których za wielość realizowanych funkcji odpowiadała inżynieria społeczna na skalę całych narodów. Obozy Gułagu zbliżały się do tego modelu, wpisane były w szerokie sieci odpowiedzialności zbiorowej (Alexopoulos 2008), acz nigdy nie realizowały planów eksterminacyjnych na masową skalę. W porównaniu z nimi wczesne systemy obozów wydają się bardzo ograniczone i ściśle związane z pragmatycznym celem (wygrana w wojnie partyzanckiej). 
Obozy, izolując zdefiniowane przez sprawców kategorie ludności, odróżniały się od innych, wcześniej istniejących instytucji, takich jak więzienia. Powstawały jako rozwiązania ekstraordynaryjne, związane z poważnymi wyzwaniami dla państwa sprawców - wojnami partyzanckimi i międzynarodowymi, rewolucjami i ludobójstwami. Choć mogły funkcjonować dekady, a zasady życia więźniów mogły być szczegółowo określone w regulaminach, to jednak cechował je nieustający „stan wyjątkowy”. Obozy stawały się narzędziami inżynierii społecznej na skalę całych populacji, zmuszając je do poddania się woli elit rządzących. Zróżnicowanie strategii życiowych członków tych populacji schodziło na dalszy plan. Stosowano logikę kolektywistyczną, w tym zbiorowej winy, co dało się zauważyć nawet wtedy, gdy wydawano wyroki na poszczególnych więźniów z zastosowaniem kodeksów karnych i tradycyjnego systemu sprawiedliwości. Wymuszało to także myślenie w kategoriach biopolitycznych, które przyjmowało jednak postać represyjnej polityki opisanej przez Agambena, a nie troski o liczebność i dobrostan populacji opisanej w modelu Foucaulta. „Najważniejszym osiągnięciem współczesnej biowładzy nie jest fabrykowanie życia i śmierci, lecz uległego i potencjalnie niekończącego się przeżycia" (Agamben 2008a, s. 156).

Hannah Arendt w Korzeniach totalitaryzmu uznaje obozy koncentracyjne i obozy zagłady reżimów totalitarnych (III Rzeszy, ZSRR i ChRL) za laboratoria, w których „poddaje się sprawdzeniu podstawowe założenia totalitaryzmu, głoszące, że wszystko jest możliwe”. Dlatego obozy stanowią wzór „totalnego panowania w ogóle” (Arendt 2014, s. 511, 512). Przeprowadzone tu porównania pokazują, że nawet jeśli Arendt ma rację, to tylko w odniesieniu do części obozów koncentracyjnych w XX wieku. Co więcej, obozy w III Rzeszy i ZSRR nie były jądrem systemu, ale jedynie jego - bez wątpienia ważną - częścią. Były co najwyżej laboratorium dla „podludzi” i „dewiantów”, a nie dla wszystkich członków wspólnoty państwowej, której wizja wyłania się z takich dokumentów, jak nazistowski Generalny Plan Wschodni (Generalplan Ost).

Jako narzędzie władzy obozy często okazywały się skuteczne. W czasie wojen partyzanckich odcinały bojowników od zaplecza i terroryzowały cywilów. Wywierały obezwładniający wpływ na całe społeczeństwo, wzmacniały władzę i zapewniały jej swobodę działania. Jako rezerwuary siły roboczej pozwalały niskim kosztem realizować wielkie projekty gospodarcze. Oczywiście, sprawcy mogli przeceniać skuteczność systemów obozów. Mogli również postrzegać jako zagrożenie populacje, które nie stanowiły realnego zagrożenia na taką skalę (np. Kikuju w Kenii). Wreszcie, same obozy mogły być źródłem problemów (np. epidemie czy ekster- 
minacja potencjalnych pracowników). Nie ulega jednak wątpliwości, że dzięki stosowanym $\mathrm{w}$ nich drastycznym środkom sprawcom udawało się osiągać zamierzone cele. Wydaje się, że obozy również dziś mogłyby spełnić swoją rolę, na przykład w czasie wojen partyzanckich w Afganistanie czy Iraku. Szczęśliwie, rozwój międzynarodowego prawa karnego i dyskursu praw człowieka czyni z nich rozwiązania zbyt kosztowne dla sprawców, choć niestety nie dla wszystkich.

Obozy stawały się przestrzeniami władzy i dominacji niezależnie od planów sprawców. Gęstość relacji władzy była różna w poszczególnych systemach obozów. Ujawniały się w nich zachowania penalizowane i usuwane $\mathrm{z}$ pola widzenia $\mathrm{w}$ czasach pokoju. Władza absolutna pozwalała strażnikom zaspokajać najbardziej wyuzdane fantazmaty. Obozy były przede wszystkim narzędziami, które miały pomóc w wygraniu wojny, wzmocnieniu i ustabilizowaniu sieci władzy lub stworzeniu nowego, posłusznego obywatela. Były tym samym częścią sieci praktyk nastawionych na pacyfikację wrogiej populacji i wewnętrznej opozycji. Ujawniły przy tym swą emergentną jakość, prowadząc do ukonstytuowania się i rozpowszechnienia sieci władzy absolutnej. Strażnicy, nawet jeśli odlegli od rasowego ideału, stawali się w praktyce nadludźmi, mogąc dręczyć, torturować i mordować więźniów oraz bezcześcić ich ciała.

Zestawienie tak różnych systemów obozów pozwala dostrzec uniwersalne idee stojące za bardzo różniącymi się ideologiami. Nie jest to zaskoczenie dla kogoś, kto nie dał się zamknąć w dyskursie wyjątkowości zbrodni nazistowskich. Ideologia i praktyka narodowosocjalistyczna była przecież zakorzeniona w zachodnioeuropejskiej myśli i postawach wobec ludów kolonialnych (Vullierme 2016). Bez wątpienia sprawców łączyła pogarda dla praw człowieka przynależnych obcym. Za tą formułą kryło się wyłączanie całych populacji z uniwersum moralnych zobowiązań. Dlatego tak często systemom obozów towarzyszyły zbrodnie wojenne, czystki etniczne czy wręcz ludobójstwa.

Nie unieważnia to tezy, że żydowscy więźniowie obozów od początku rządu nazistów byli ofiarami najbardziej okrutnych praktyk. Jeszcze zanim w 1941 roku podjęto decyzję, że przeprowadzone zostanie ludobójstwo totalne, mordowano ich, niejednokrotnie nie zważając na własne interesy (np. eksterminowano cennych specjalistów). Mimo retoryki niemieckiego porządku Niemcy na ogromną skalę dopuszczali się sadystycznych ekscesów także wobec wszystkich okupowanych narodów. Wyjątkowość tego doświadczenia możemy dostrzec dzięki porównaniom, które dowodzą bezprecedensowości niemieckiego systemu terroru. 


\section{BIBLIOGRAFIA}

Abel Theodore, 1951, The Sociology of Concentration Camps, „Social Forces”, t. 30(2), s. 150-155 .

Agamben Giorgio, 2008a, Co zostaje z Auschwitz. Archiwum i świadek (Homo sacer III), tłum. Sławomir Królak, Wydawnictwo Sic!, Warszawa.

Agamben Giorgio, 2008b, Homo sacer. Suwerenna władza i nagie życie, tłum. Mateusz Salwa, Prószyński i S-ka, Warszawa.

Alexopoulos Golfo, 2005, Amnesty 1945: The Revolving Door of Stalin's Gulag, „Slavic Review”, t. $64(2)$, s. $274-306$.

Alexopoulos Golfo, 2008, Stalin and the Politics of Kinship: Practices of Collective Punishment, 1920s-1940s, „Comparative Studies in Society and History”, t. 50(1), s. 91-117.

Alexopoulos Golfo, 2016, Medical Research in Stalin's Gulag, „Bulletin of the History of Medicine", t. 90(3), s. 363-393.

Applebaum Anne, 2005, Gułag, tłum. Jakub Urbański, Świat Książki, Warszawa.

Arendt Hannah, 2014, Korzenie totalitaryzmu, tłum. Daniel Grinberg, Mariola Szawiel, Świat Książki, Warszawa.

Baader Gerhard, Lederer Susan E., Low Morris, Schmaltz Florian, Schwerin Alexander V., 2005, Pathways to Human Experimentation, 1933-1945: Germany, Japan, and the United States, „Osiris”, $2^{\text {nd }}$ Series, t. 20: „Politics and Science in Wartime: Comparative International Perspectives on the Kaiser Wilhelm Institute", s. 205-231.

Birtle Andrew J., 1997, The U.S. Army's Pacification of Marinduque, Philippine Islands, April 1900 -April 1901, „The Journal of Military History”, t. 61(2), s. 255-282.

Boose Lynda E., 2002, Crossing the River Drina: Bosnian Rape Camps, Turkish Impalement, and Serb Cultural Memory, „Signs”, t. 28, nr 1: „Gender and Cultural Memory”, s. 71-96.

Browning Christopher R., 2012, Pamięć przetrwania. Nazistowski obóz pracy oczami więźniów, tłum. Hanna Pustuła-Lewicka, Wydawnictwo Czarne, Wołowiec.

Buggeln Marc, 2008, Were Concentration Camp Prisoners Slaves?: The Possibilities and Limits of Comparative History and Global Historical Perspectives, „International Review of Social History”, t. 53, s. 101-129.

Chamayou Grégoire, 2012, Podte ciała. Eksperymenty na ludziach w XVIII $i$ XIX wieku, tłum. Jadwiga Bodzińska, Katarzyna Thiel-Jańczuk, Słowo/obraz terytoria, Gdańsk.

De Reuck Jenny, 1999, Social Suffering and the Politics of Pain: Observations on the Concentration Camps in the Anglo-Boer War 1899-1902, „English in Africa”, t. 26(2), s. 69-88.

Des Pres Terrence, 1980, The Survivor: An Anatomy of Life in the Death Camps, Oxford University Press, Oxford-New York.

Diken Bülent, 2011, Od obozów dla uchodźców do osiedli grodzonych. Biopolityka i koniec miasta, „Praktyka Teoretyczna”, nr 2-3, s. 126-140.

Dower John W., 1993, War without Mercy: Race and Power in the Pacific War, Pantheon Books, New York.

Drakulić Slavenka, 2006, Oni nie skrzywdziliby nawet muchy. Zbrodniarze wojenni przed Trybunatem w Hadze, tłum. Jakub Szacki, Wydawnictwo W.A.B., Warszawa.

Durkheim Émile, 2006, Samobójstwo. Studium z socjologii, tłum. Krzysztof Wakar, Oficyna Naukowa, Warszawa.

Eitzen Edward M., Jr., Takafuji, Ernest T., 1997, Historical Overview of Biological Warfare, w: Frederick R. Sidell, Ernest T. Takafuji, David R. Franz (red.), Medical Aspects of Chemical and 
Biological Warfare (Textbook of Military Medicine), United States Army Medical Department, s. 415-423.

Elkins Caroline, 2013, Rozliczenie z imperium. Przemilczana historia brytyjskich obozów w Kenii, tłum. Klara Kopcińska, Świat Książki, Warszawa.

Etcheson Craig, 2004, The Cambodian Genocide, w: Samuel Totten (red.), Teaching about Genocide: Issues, Approaches and Resources, Information Age Publishing, Greenwich, s. 169$-181$.

Fein Helen, 1993, Genocide: A Sociological Perspective, Sage Publications, London.

Filinowicz Natalia, 2013, Życie amerykańskich Japończyków w obozach internowania, „Białostockie Teki Historyczne", t. 11, s. 211-230.

Foucault Michel, 1998, Trzeba bronić społeczeństwa. Wykłady w Collège de France, 1976, tłum. Małgorzata Kowalska, Wydawnictwo KR, Warszawa.

Goeschel Christian, 2010, Suicide in Nazi Concentration Camps, 1933-9, „Journal of Contemporary History", t. 45(3), s. 628-648.

Grabowska Janina, 1977, Dzieci i więźniowie małoletni w obozie koncentracyjnym Stutthof, „Zeszyty Muzeum Stutthof", nr 2, s. 33-55.

Harris Victoria, 2010, The Role of the Concentration Camps in the Nazi Repression of Prostitutes, 1933-9, „Journal of Contemporary History”, t. 45(3), s. 675-698.

Heger Heinz, 2016, Mężczyźni z różowym trójkątem. Świadectwo homoseksualnego więźnia obozu koncentracyjnego z lat 1939-1945, tłum. Alicja Rosenau, Ośrodek Karta, Warszawa.

Hilberg Raul, 2014, Zagłada Żydów europejskich, t. 1-3, tłum. Jerzy Giebułtowski, Wydawca: Piotr Stefaniuk, Warszawa.

Hinton Alexander Laban, 1998, A Head for an Eye: Revenge in the Cambodian Genocide, „American Ethnologist", t. 25(3), s. 352-377.

Jelonek Adam W., 1999, Rewolucja Czerwonych Khmerów 1975-1978. Studium autarkicznego rozwoju, Scholar, Warszawa.

Jelonek Adam W., 2008, Kambodża, Wydawnictwo Trio, Warszawa.

Kalbarczyk Sławomir, 2009, Gułag: Niewolnictwo XX wieku, „Biuletyn Instytutu Pamięci Narodowej" nr 4(99), s. 11-23.

Kamiński Andrzej Józef, 1990, Koszmar niewolnictwa. Obozy koncentracyjne od 1896 do dziś. Analiza, tłum. Halina Zarychta i autor, Wydawnictwo Przedświt, Warszawa.

Khlevnyuk Oleg, 2001, The Economy of the Gulag, w: Paul R. Gregory (red.), Behind the Façade of Stalin's Command Economy, Hoover Institution Press, Stanford, s. 111-129.

Kiernan Ben, 2003, Twentieth-century Genocides. Underlying Ideological Themes from Armenia to East Timor, w: Robert Gellately, Ben Kiernan (red.), The Specter of Genocide. Mass Murder in Historical Perspective, Cambridge University Press, Cambridge, s. 29-51.

Kiernan Ben, 2007, Blood and Soil. A World History of Genocide and Extermination from Sparta to Darfur, Yale University Press, New Haven, London.

Klee Ernst, 2005, Auschwitz. Medycyna III Rzeszy i jej ofiary, tłum. Elżbieta Kalinowska-Styczeń, Universitas, Kraków.

Kłys Agnieszka, 2018, Psy w stużbie zła. Oddział Hundestaffel w obozie Stutthof, w: Alicja Bartuś (red.), Jak rodzi się zło. Sprawcy, wykonawcy, pomocnicy, Biblioteka Galeria Książki w Oświęcimiu, Fundacja na Rzecz MDSM, Oświęcim, s. 113-121.

Konecki Krzysztof, 1985, Jaźń w totalnej instytucji obozu koncentracyjnego, „Kultura i Społeczeństwo", nr 3, s. 197-211. 
Korb Alexander, 2014, The Disposal of Corpses in an Ehnicized Civil War: Croatia, 1941-45, w: Jean-Marc Dreyfus, Élisabeth Anstett (red.), Human Remains and Mass Violence. Methodological Approaches, Manchester University Press, Manchester, s. 106-128.

Leśniewski Michał, 2006, Wojna brytyjsko-burska (1899-1902), w: Piotr Ostaszewski (red.), Konflikty kolonialne i postkolonialne w Afryce i Azji 1869-2006, Książka i Wiedza, Warszawa, s. 96-108.

Libionka Dariusz, 2017, Zagłada Żydów w Generalnym Gubernatorstwie. Zarys problematyki, Państwowe Muzeum na Majdanku, Lublin.

López-Muñoz Francisco, Cuerda-Galindo Esther, 2016, Suicide in Inmates in Nazis and Soviet Concentration Camps: Historical Overview and Critique, „Frontiers in Psychiatry”, t. 7, Article 88, s. 1-6.

Łuszczyna Marek, 2017, Mała zbrodnia. Polskie obozy koncentracyjne, Znak, Kraków.

Maher Thomas V., 2010, Threat, Resistance, and Collective Action: The Cases of Sobibór, Treblinka, and Auschwitz, „American Sociological Review”, t. 75(2), s. 252-272.

Mann Michael, 2006, The Dark Side of Democracy: Explaining Ethnic Cleansing, Cambridge University Press, Cambridge.

Markusen Eric, 2004, Genocide in Bosnia, w: Samuel Totten (red.), Teaching about Genocide: Issues, Approaches, and Resources, Information Age Publishing, Greenwich, s. 193-202.

Margolin Jean-Louis, 2009, Japonia 1937-1945. Wojna Armii Cesarza, tłum. Joanna P. Rurarz, Agnieszka Rurarz, Wydawnictwo Akademickie Dialog, Warszawa.

McCormack Gavan, 2003, Reflections on Modern Japanese History in the Context of the Concept of Genocide, w: Robert Gellately, Ben Kiernan (red.), The Specter of Genocide. Mass Murder in Historical Perspective, Cambridge University Press, Cambridge, s. 265-286.

Modrzejewska-Leśniewska Joanna, 2006, Wojna w Algierii 1954-1962, w: Piotr Ostaszewski (red.), Konflikty kolonialne i postkolonialne w Afryce i Azji 1869-2006, Książka i Wiedza, Warszawa, s. 374-383.

Mularska-Andziak Lidia, 2006, Wojna o Kubę i Filipiny (1898), w: Piotr Ostaszewski (red.), Konflikty kolonialne i postkolonialne w Afryce i Azji 1869-2006, Książka i Wiedza, Warszawa, s. 58-64.

Musielak Michał, 2008, Sterylizacja ludzi ze względów eugenicznych $w$ Stanach Zjednoczonych, Niemczech i w Polsce (1899-1945). Wybrane problemy, Wydawnictwo Poznańskie, Poznań.

Nowak Edmund, 2002, Obozy na Ślasku Opolskim w systemie powojennych obozów w Polsce (1945-1950). Historia i implikacje, Wydawnictwo Uniwersytetu Opolskiego, Opole.

Olusoga David, Erichsen Casper, 2012, Zbrodnia kajzera, tłum. Piotr Tarczyński, Wydawnictwo Wielka Litera, Warszawa.

Ostrowska Joanna, 2018, Przemilczane. Seksualna praca przymusowa w czasie II wojny światowej, Wydawnictwo Marginesy, Warszawa.

Pawełczak Marek, 2004, Kenia, Wydawnictwo Trio, Warszawa.

Pawełczyńska Anna, 1973, Wartości a przemoc. Zarys socjologicznej problematyki Oświęcimia, Państwowe Wydawnictwo Naukowe, Warszawa.

Rogut Dariusz, 2010, Zarys historii sowieckiego obozu specjalnego nr 4 (Stieptagu) w latach 1948-1954, „Pamięć i Sprawiedliwość” nr 2, s. 273-293.

Russell Timothy D., 2014, "I feel sorry for these people": African American Soldiers in the Philippine-American War, 1899-1902, „The Journal of African American History”, t. 99(3), s. 197-222 . 
Schafft Gretchen E., 2006, Od rasizmu do ludobójstwa. Antropologia w Trzeciej Rzeszy, tłum. Teresa Bałuk-Ulewiczowa, Wydawnictwo Uniwersytetu Jagiellońskiego, Kraków.

Semelin Jacques, 2003, Analysis of Mass Crime: Ethnic Cleansing in the Former Yugoslavia 1991-1999, w: Robert Gellately, Ben Kiernan (red.), The Specter of Genocide: Mass Murder in Historical Perspective, Cambridge University Press, Cambridge, s. 353-370.

Skocpol Theda, 1994, Social Revolutions in the Modern World, Cambridge University Press, Cambridge.

Snyder Timothy, 2011, Skrwawione ziemie. Europa między Hitlerem a Stalinem, tłum. Bartłomiej Pietrzyk, Świat Książki, Warszawa.

Sofsky Wolfgang, 1999, Traktat o przemocy, tłum Marek Adamski, Wydawnictwo Dolnośląskie, Wrocław.

Sofsky Wolfgang, 2016, Ustrój terroru. Obóz koncentracyjny, tłum. Małgorzata Łukasiewicz, Żydowski Instytut Historyczny, Warszawa.

Strzelecka Irena, 1995, Kary i tortury, w: Wacław Długoborski, Fraciszek Piper (red.), Auschwitz 1940-1945. Węzłowe zagadnienia z dziejów obozu, t. 2: Więźniowie - życie i praca, Wydawnictwo Państwowego Muzeum, Oświęcim-Brzezinka, s. 277-292.

Sutton Keith, 1977, Population Resettlement - Traumatic Upheavals and the Algerian Experience, „The Journal of Modern African Studies”, t. 15(2), s. 279-300.

Śleszyński Wojciech, 2003, Utworzenie i funkcjonowanie obozu odosobnienia w Berezie Kartuskiej (1934-1939), „Dzieje Najnowsze”, nr 2, s. 35-53.

Ther Philipp, 2012, Ciemna strona państw narodowych. Czystki etniczne w nowoczesnej Europie, tłum. Tomasz Gabiś, Wydawnictwo Poznańskie, Poznań.

van Heyningen Elizabeth, 2010, A Tool for Modernisation? The Boer Concentration Camps of the South African War, 1900-1902, „South African Journal of Science”, t. 106(5/6), Art. \#242.

Vulliamy Ed, 2016, Wojna umarła, niech żyje wojna. Bośniackie rozrachunki, tłum. Janusz Ochab, Wydawnictwo Czarne, Wołowiec.

Vullierme Jean-Louis, 2016, Lustro Zachodu. Nazizm i cywilizacja zachodnia, tłum. Maria Żurowska, Grupa Wydawnicza Foksal, Warszawa.

Wachsmann Nikolaus, 2016, Historia nazistowskich obozów koncentracyjnych, tłum. Maciej Antosiewicz, Świat Książki, Warszawa.

Walkiewicz Wiesław, 2000, Jugosławia. Byt wspólny i rozpad, Wydawnictwo Trio, Warszawa.

Welch Jr. Richard E., 1974, American Atrocities in the Philippines: The Indictment and the Response, „Pacific Historical Review”, t. 43(2), s. 233-253.

Werth Nicolas, 2010, Mass Deportations, Ethnic Cleansing, and Genocidal Politics in the Later Russian Empire and the USSR, w: Donald Bloxham, A. Dirk Moses (red.), The Oxford Handbook of Genocide Studies, Oxford University Press, Oxford, s. 386-406.

Wesołowska Danuta, 1996, Słowa z piekiet rodem. Lagerszpracha [totalitaryzm i język], Impuls, Kraków

Witek-Malicka Wanda, 2013, Dzieci z Auschwitz-Birkenau. Socjalizacja w obozie koncentracyjnym na przykładzie Dzieci Oświęcimia, Uniwersytet Śląski w Katowicach, Nomos, Kraków.

Wright Erik O., 2006, Klasy się licza, w: Aleksandra Jasińska-Kania, Lech M. Nijakowski, Jerzy Szacki, Marek Ziółkowski (wyb. i oprac.), Współczesne teorie socjologiczne. Antologia tekstów, t. 2, Scholar, Warszawa, s. 813-832.

Yap Felicia, 2012, Prisoners of War and Civilian Internees of the Japanese in British Asia: The Similarities and Contrasts of Experience, „Journal of Contemporary History”, t. 47(2), s. 317-346. 


\section{CONCENTRATION CAMPS AS A TWENTIETH-CENTURY TOOL OF POWER AND SOCIAL TRANSFORMATION}

Lech M. Nijakowski

(University of Warsaw)

\section{Abstract}

The author compares 12 concentration camp systems, from US camps in the Philippines (1901-1902) to Serbian, Croatian, and Bosnian camps in Bosnia and Herzegovina (1992-1995). He uses comparative history for macro-causal analysis, discusses the challenges in defining concentration camps, and compares camps with other institutions. Some of the features outlined in the paper can be found in all concentration camps (forceful isolation of masses of people in accord with a "collectivist logic," power, and cruelty), while others are limited to certain sub-types (forced labor, medical experiments). The author proves that concentration camps were predominantly a tool that was intended to help win wars, reinforce and stabilize power, and create a new, obedient form of citizen. Therefore, camps were one of the many methods used to pacify hostile populations and internal opposition. At the same time, their potential became apparent and led to the rise and spread of absolute power structures.

\section{Key Words / słowa kluczowe}

concentration camp / obóz koncentracyjny, comparative historical sociology / porównawcza socjologia historyczna, absolute power / władza absolutna, genocide studies / studia nad ludobójstwem 